\title{
Stages of Behavior Change for physical activity and associated factors among technical- administrative servers of a federal university
}

\section{Estágios de Mudança de Comportamento para a atividade física e fatores associados em servidores técnico-administrativos de uma universidade federal}

\author{
Juliane Berria \\ Davi Monteiro Teixeira \\ Giseli Minatto \\ Edio Luiz Petroski ${ }^{\dagger}$
}

Abstract - The benefits that the regular practice of physical activity (PA) provides to health and its importance in preventing and fighting chronic diseases. The aim of this study was to identify the Stages of Behavior Change (SBC) for PA among technicaladministrative servers and its association with sociodemographic and health risk factors. This cross-sectional study investigated 622 technical-administrative servers (337 women) from a Brazilian federal university. SBC for PA, sociodemographic information (gender, age, marital status and educational level) and health risk factors (inadequate eating habits, excessive alcohol consumption, smoking, commuting and PA at work) were collected through questionnaires. Multinomial regression with adjustment for the hierarchical level was applied and significance level of 5\% was adopted. The distribution of technical-administrative servers in SBC for PA identified prevalence of $9.1 \%$ and $6.5 \%$ in the pre-contemplation stage, $24.6 \%$ and $33.5 \%$ in contemplation, $33.3 \%$ and $226 \%$ in preparation, $5.6 \%$ and $12.2 \%$ in action and $27.4 \%$ and $25.2 \%$ in maintenance stages between men and women, respectively. Lower odds ratio of being in the preparation stage was identified among women $(\mathrm{OR}=0.62 ; \mathrm{CI} 95 \%=0.41 ; 0.93)$ while those with inadequate eating habits were more odds to be in the "pre-contemplation + contemplation" $(\mathrm{OR}=2.77$; CI95\%=1.85; 4.15) and preparation stages $(\mathrm{OR}=1.75 ; \mathrm{CI} 95 \%=1.12 ; 2.70)$. Over $60 \%$ of technical-administrative servers are insufficiently active (pre-contemplation, contemplation and preparation stages) and factors associated with SBC were female sex and inadequate eating habits.

Key words: Educational status, Motor activity, Occupational health.

Resumo - Os benefícios que a atividade física $(A F)$ regular proporciona à saúde e a sua importância para prevenir e combater doenças crônicas não transmissiveis. Objetivou-se identificar os Estágios de Mudança de Comportamento (EMC) para a AF em servidores técnico-administrativos e sua associação com fatores sociodemográficos e de risco a saúde. Este estudo transversal investigou 622 servidores (337 mulheres) técnico-administrativos de uma universidade federal brasileira. Foram coletados os EMC para a AF, informaçôes sociodemográficas (sexo, idade, estado civil e escolaridade) e fatores de risco à saúde (hábitos alimentares inadequados, consumo excessivo de álcool, tabagismo, forma de deslocamento e AF no trabalho) por meio de questionários. Aplicou-se a regressão multinomial com ajuste por nivel hierárquico e adotou-se nivel de significância de 5\%. A distribuição dos servidores nos EMC para a AF identificou prevalência de 9,1\% e 6,5\% no estágio de pré-contemplação, 24,6\% e 33,5\% de contemplação, 33,3\% e 22,6\% de preparação, $5,6 \%$ e 12,2\% de ação e 27,4\% e 25,2\% de manutenção entre homens e mulheres, respectivamente. Menor chance de estar no estágio de preparação foi identificada entre as mulheres (RC: 0,62; IC95\%: 0,41; 0,93) enquanto aqueles com hábitos alimentares inadequados apresentaram maior chance de estar nos estágios de pré-contemplação + contemplação (RC: 2,77; IC95\%:1,85; 4,15) e preparação (RC: 1,75; IC95\%: 1,12; 2,70). Mais de 60\% dos servidores da instituição são insuficientemente ativos (estágios de pré-contemplação, contemplação e preparação) e os fatores associados aos EMC foram o sexo feminino e os hábitos alimentares inadequados.

Palavras-chave: Atividade motora, Escolaridade, Saúde do trabalhador.
1 Federal University of Santa Catarina. Center for Research in Kinanthropometry and Human Performance. Florianópolis, Santa Catarina, Brasil.

Received: 13 September 2015 Accepted: 01 June 2016 


\section{INTRODUCTION}

The benefits that the regular practice of physical activity (PA) provides to health and its importance in preventing and fighting chronic diseases such as obesity, heart disease, hypertension, type 2 diabetes, musculoskeletal diseases and even some forms of cancer have been widely reported in literature ${ }^{1-3}$.

Despite the offer of information provided by science on the subject, low levels of regular PA have been found in different population groups. Regarding workers, this factor may predispose occupational disorders such as repetitive strain injury (RSI) and work-related musculoskeletal disorders $(\mathrm{WRMD})^{4}$. Moreover, it is known that work demands can influence the practice of PA during leisure time ${ }^{5,6}$.

The transtheoretical model proposed by Prochaska and Marcus ${ }^{7}$ has been useful for investigating the behavior of individuals related to PA, as it indicates the exact behavior stage the subject is found ${ }^{8}$. This is crucial as it informs the current stage of the subject evaluated, which allows directing actions of specific interventions for each stage. For example, physically active individuals include those who began practicing PA recently and are more likely to drop it out, and also those who have already incorporated the practice of PA into their lifestyle. Among those insufficiently active, there are those who have no intention of starting a PA program and also those who wish to practice it in the near future9.

Literature indicates that women are more likely to be in the early stages for PA when compared to males. Furthermore, a systematic review showed that young people, white skin, single, higher schooling, non-smokers, normal weight and with with higher level of PA and physical fitness are more likely to be in more advanced stages for $\mathrm{PA}^{9}$.

In Brazil, few studies using the SBC to research $\mathrm{PA}$ in public servers or others workers have been identified ${ }^{10}$. It is known that work characteristics can influence the practice of PA and that the determination SBC for PA can help in the development of more effective interventions to promote PA for this population while enabling adapt strategies for each stage of readiness. Thus, the objective of this study was to investigate which stages of behavior change (SBC) for PA technical-administrative servers of a Brazilian federal university are and which sociodemographic and health risk factors are associated with SBC for PA. We hypothesized that which sociodemographic and health risk factors are associated which SBC for PA can be different between stages.

\section{METHODOLOGICAL PROCEDURES}

\section{Population and sample}

This study was based on data from the epidemiological survey "Lifestyle, PA, body image perception and health risk factors among technical-administrative servers of the Federal University of Santa Catarina (UFSC)", 
approved by the Ethics Committee of Research with Human Beings of the Federal University of Santa Catarina (UFSC), protocol No. 27939/13.

The study population consisted of 2,993 technical-administrative servers (171 auxiliary level, 1,823 intermediate level, and 999 upper level) of UFSC. Sample calculation adopted confidence level of 95\% (CI 95\%), unknown prevalence for the outcome of 50\%, sampling error of 3.5 percentage points plus $20 \%$ for potential losses and refusals. The estimated sample was 746 technical-administrative servers.

The sample selection was stratified proportionally by level (auxiliary, intermediate and upper). Overall, 43 auxiliary-level, 456 intermediate-level, and 25 upper-level technical-administrative servers were randomly and systematically selected to compose the sample, totaling 749 workers. Sample replacement was performed in the case of absence, leave, resignation, retirement, those assigned to other institutions, those who had resigned and those that could not be located due to lack of information about the current workplace, totaling 54 replacements. All technical-administrative servers were eligible to participate. Those who refused to answer questions regarding $\mathrm{SBC}$ for $\mathrm{PA}$ were excluded from the analyses.

\section{Instruments}

SBC for PA were verified through questionnaire proposed by Marcus ${ }^{11}$, which classifies individuals from five stages: 1) Pre-contemplation (individual does not intend to change behavior in the near future); 2) Contemplation (there is intention to change behavior, but not immediately); 3) Preparation (individual is not engaged in PA on a regular basis, but intends to do it within the next 30 days); 4) Action (individual is regularly active for less than six months), and 5) Maintenance (individual is active on a regular basis for at least six months).

Sociodemographic variables were gender (male and female), age (2029; 30-39; 40-49; 50-59 and 60-69 years), marital status (single, married, separated / widowed) and schooling ( $\geq 12$ years; 9-11 years and $\leq 8$ years).

The following health risk factors: inadequate eating habits, smoking, and excessive alcohol consumption were determined from self-administered questionnaire "Fantastic Life Style" of the Canadian Association of Physiology ${ }^{12}$, translated and validated into Portuguese (Cronbach $\alpha$ 0.69; $\mathrm{R}=0.92)^{13}$.

Eating habits were assessed using the question: "I eat a balanced diet," (Cronbach $\alpha 0.69 ; 0.72$ ) which considers the consumption of five to 12 daily servings of grains and cereals, five to 10 daily servings of fruits and vegetables, two to three daily servings of meat and similar and two to four daily servings of dairy products. Response alternatives were almost always and always classified as "adequate eating habits" and sometimes, rarely, and almost never as "inadequate eating habits".

The consumption of alcoholic beverages has been identified using the question: "My average weekly alcohol intake is?" (Cronbach $\alpha$ 0.67; $\mathrm{R}=0.88$ ).The ingestion of more than 20 doses and 13 to 20 doses per week 
was considered "excessive alcohol consumption" and 11 to 12 doses, 10 doses and eight to zero to seven doses per week as "not excessive alcohol consumption".

The question "I smoke cigarettes" (Cronbach $\alpha 0.69 ; \mathrm{R}=0.86$ ) was used to assess tobacco use. Technical-administrative servers that marked the following alternatives: more than 10 per day and from one to 10 per day, were categorized as "smokers" and those who answered none in the last six months, last year or last five years as "nonsmokers".

Sedentary behavior was identified through questionnaire proposed and validated by Barros ${ }^{14}$ and modified by Fonseca ${ }^{15}$. Sedentary behavior in displacement was identified using the question: "On most days of the week, how do you get to work?" Going to work on foot and bicycle was considered "active commuting" and bus, car or motorbike as "little active commuting". The question "Your activities at work can be described as:" I spend most time sitting (a) and I walk short distances ("sitting"); most of the day I perform moderate physical activities such as fast walks or manual tasks ("moderate activities"); I often perform intense physical activities ("intense activities"), was used to characterize sedentary behavior at work.

\section{Statistical analysis}

Sample characterization was performed by means of central tendency and dispersion measurements. Although $\mathrm{SBC}$ for PA (outcome) is not a disease, prevalence was referred to as the proportion of workers who are at each stage of the outcome. Differences between proportions of SBC for $\mathrm{PA}$ in relation to the study variables were analyzed using the chi-square test. Multinomial logistic regression was used to assess the association of workers in "preparation" and "pre-contemplation + contemplation" stages and the study variables, and odds ratios (OR) and confidence intervals of 95\% (CI 95\%) were estimated in crude and adjusted analyses. Hierarchical model ${ }^{16}$ was adopted in three levels, considering the hypothetical temporal relationship of variables, being, $1^{\text {st }}$ level: demographic variables (gender, age); $2^{\text {nd }}$ level: socioeconomic variable (schooling and marital status) and $3^{\text {rd }}$ level: behavioral variables (eating habits, excessive alcohol consumption, smoking, commuting and work activities). Variables were controlled at each level of the hierarchical model and by those of previous levels that showed $p \leq 0.20$. The confidence level for all analyses was $95 \%$. Data analysis was conducted by the Statistical Package for Social Sciences (SPSS) software version 15.0.

\section{RESULTS}

Of the 749 technical-administrative servers at UFSC selected to compose the sample, 623 participated in the survey, 83 refused to participate and there were 43 losses due to vacation $(n=16)$, medical certificate $(n=16)$ and for failing to contact in the period of data collection $(n=11)$. Only one worker that refused to answer questions relating to $\mathrm{SBC}$ for PA was 
excluded from this study. Thus, the sample was composed of 622 technical-administrative servers, 285 men and 337 women. Table 1 shows that losses and refusals were higher among males, but no difference between occupational level was observed.

Table 1. Relative frequency of the selected sample collected, losses and refusals according to sex and occupational level. Florianópolis, SC, Brazil, 2012.

\begin{tabular}{|c|c|c|c|c|c|}
\hline Variables & $\begin{array}{c}\text { Total } \\
(n=749)\end{array}$ & $\begin{array}{l}\text { Sample } \\
(\mathrm{n}=622)\end{array}$ & $\begin{array}{l}\text { Losses and refusals } \\
\qquad(n=127)\end{array}$ & Chi-square & $p$-value \\
\hline & $\%$ & $\%$ & $\%$ & & \\
\hline Sex & & & & 7.401 & 0.01 \\
\hline Men & 48.1 & 79.2 & 20.8 & & \\
\hline Women & 51.9 & 86.6 & 13.6 & & \\
\hline Occupational level & & & & 1.204 & 0.55 \\
\hline Auxiliary & 6.0 & 88.9 & 11.1 & & \\
\hline Intermediate & 60.9 & 82.5 & 17.5 & & \\
\hline Superior & 33.1 & 83.1 & 16.9 & & \\
\hline
\end{tabular}

The distribution of workers according to SBC for PA indicates that most women intend to become active in the next six months (CI 95\%: $28.47 ; 38.6)$ and men are physically active, but not on a regular basis (CI 95\%: 27.93; 38.84) (Figure 1). Differences in the proportions of men and women were identified in the stages of preparation (men CI 95\%: 27.93; 38.84 and women CI 95\%: 18.07; 27.04) and action (men CI 95\%: 2.93; 8.30 and women CI 95\%: 8.66; 15.67).

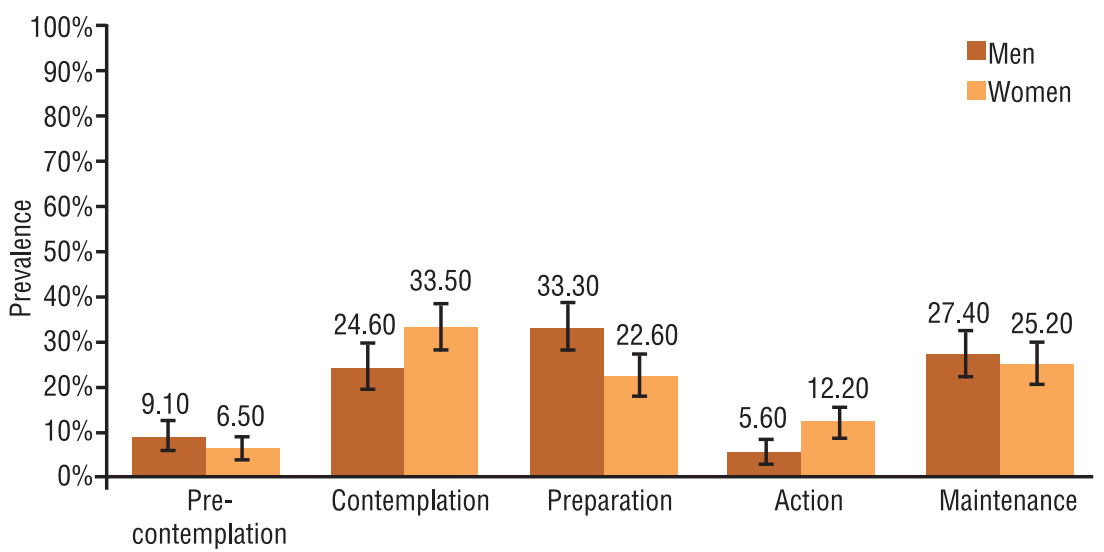

Figure 1. Distribution of servers in stages of behavior change for physical activity. Florianopolis, SC, Brazil, 2012.

The prevalence of workers in "pre-contemplation + contemplation" stages was $33.7 \%$ among men and $40.1 \%$ among women, in "preparation" stage, this prevalence was $33.3 \%$ among men and $22.6 \%$ among women and in "action + maintenance" stages, prevalence was 33.0\% among men and $37.4 \%$ among women (Table 2).

A Greater proportion of workers in "pre-contemplation +contemplation" stage was observed among those with inadequate eating habits (47.2\%) and who perform intense PA at work (41.7\%). SBC in the "preparation" 
stage, highest proportion was found in workers with inadequate eating habits (28.4\%) and those who remain sat at work (31.3\%), while in "action + maintenance" stages, most workers have adequate eating habits (43.4\%) and perform intense PA at work (58.3\%) (Table 2).

Table 2. General distribution of the sample in stages of behavior change for physical activity according to the sociodemographic indicators and health risk factors in technical-administrative servers of UFSC. Florianopolis, SC, Brazil, 2012.

\begin{tabular}{|c|c|c|c|c|c|c|c|c|}
\hline \multirow[t]{2}{*}{ Variables } & \multicolumn{2}{|c|}{$\begin{array}{c}\text { Precontemplation + } \\
\text { Contemplation }\end{array}$} & \multicolumn{2}{|c|}{ Preparation } & \multicolumn{2}{|c|}{ Action + Maintenance } & \multirow[t]{2}{*}{$\begin{array}{c}\text { Chi- } \\
\text { square }\end{array}$} & \multirow[t]{2}{*}{$p$-value } \\
\hline & $\mathrm{n}$ & $\%$ & $\mathrm{n}$ & $\%$ & $n$ & $\%$ & & \\
\hline Sex & & & & & & & 9.066 & 0.011 \\
\hline Men & 96 & 33.7 & 95 & 33.3 & 94 & 33.0 & & \\
\hline Women & 135 & 40.1 & 76 & 22.6 & 26 & 37.4 & & \\
\hline Age (years) & & & & & & & 8.786 & 0.361 \\
\hline $20-29$ & 28 & 41.2 & 14 & 20.6 & 26 & 38.2 & & \\
\hline $30-39$ & 40 & 32.5 & 29 & 23.6 & 54 & 43.9 & & \\
\hline $40-49$ & 67 & 39.0 & 53 & 30.8 & 52 & 30.2 & & \\
\hline $50-59$ & 80 & 36.2 & 66 & 29.9 & 75 & 33.9 & & \\
\hline $60-69$ & 16 & 42.1 & 9 & 23.7 & 13 & 34.2 & & \\
\hline Marital Status & & & & & & & 2.429 & 0.657 \\
\hline Single & 59 & 36.9 & 39 & 24.4 & 62 & 38.8 & & \\
\hline Married & 137 & 36.8 & 110 & 26.9 & 125 & 33.6 & & \\
\hline Separated/Widowed & 35 & 38.9 & 22 & 24.4 & 33 & 36.7 & & \\
\hline Education & & & & & & & 4.933 & 0.294 \\
\hline$\geq 12$ years & 149 & 34.2 & 126 & 28.9 & 161 & 36.9 & & \\
\hline 9 to 11 years & 64 & 43.2 & 37 & 25.0 & 47 & 31.8 & & \\
\hline$\leq 8$ years & 16 & 44.4 & 8 & 22.2 & 12 & 33.3 & & \\
\hline Eating Habits & & & & & & & 27.553 & $<0.001$ \\
\hline Adequate & 107 & 29.6 & 98 & 27.1 & 157 & 43.4 & & \\
\hline Inadequate & 118 & 47.2 & 71 & 28.4 & 61 & 24.4 & & \\
\hline Excessive Alcohol Consumption & & & & & & & 3,970 & 0.137 \\
\hline No & 224 & 37.5 & 159 & 26.6 & 214 & 35.8 & & \\
\hline Yes & 7 & 31.8 & 10 & 45.5 & 5 & 22.7 & & \\
\hline Smoking & & & & & & & 2.115 & 0.347 \\
\hline No & 203 & 37.3 & 145 & 26.7 & 196 & 36.0 & & \\
\hline Yes & 24 & 34.8 & 24 & 34.8 & 21 & 30.4 & & \\
\hline Displacement & & & & & & & 2.011 & 0.366 \\
\hline Active & 27 & 36.5 & 16 & 21.6 & 31 & 41.9 & & \\
\hline Not active & 203 & 37.2 & 154 & 28.2 & 189 & 34.6 & & \\
\hline Activities at work & & & & & & & 9.541 & 0.033 \\
\hline Intense PA & 5 & 41.7 & - & - & 7 & 58.3 & & \\
\hline Moderate PA & 94 & 38.1 & 59 & 23.9 & 94 & 38.1 & & \\
\hline Sitting & 129 & 36.0 & 112 & 31.3 & 117 & 32.7 & & \\
\hline
\end{tabular}

v Technical-administrative servers with inadequate eating habits were $277 \%$ more odds to be in the "pre-contemplation + contemplation" stages compared to those with adequate eating habits. The remaining variables were not associated with "pre-contemplation + contemplation" stages (Table 3). 
Table 3. Odds ratios and confidence intervals for the crude and adjusted analyzes between the stages of behavior change "pre-contemplation + contemplation" and sociodemographic indicators and health risk factors in technical-administrative servers of UFSC. Florianopolis, SC, Brazil, 2012.

\begin{tabular}{|c|c|c|c|c|}
\hline \multirow{2}{*}{ Variables } & \multicolumn{4}{|c|}{ Precontemplation + Contemplation } \\
\hline & OR (CI95\%)† & Value $p$ & OR (Cl95\%)†† & Value $p$ \\
\hline \multicolumn{5}{|l|}{$\operatorname{Sex}^{1}$} \\
\hline Men & 1 & & 1 & \\
\hline Women & $1.05(0.72 ; 1.52)$ & 0.802 & $1.08(0.74 ; 1.59)$ & 0.668 \\
\hline \multicolumn{5}{|l|}{ Age (years) ${ }^{1}$} \\
\hline $20-29$ & 1 & & 1 & \\
\hline $30-39$ & $0.69(0.35 ; 1.35)$ & 0.275 & $1.17(0.47 ; 2.90)$ & 0.740 \\
\hline $40-49$ & $1.29(0.63 ; 2.28)$ & 0.586 & $1.00(0.54 ; 1.87)$ & 0.991 \\
\hline $50-59$ & $0.99(0.53 ; 1.84)$ & 0.976 & $1.20(0.63 ; 2.30)$ & 0.571 \\
\hline $60-69$ & $1.14(0.46 ; 2.83)$ & 0.773 & $0.69(0.35 ; 1.35)$ & 0.275 \\
\hline \multicolumn{5}{|l|}{ Education $^{2}$} \\
\hline$\geq 12$ years & 1 & & 1 & \\
\hline 9 to 11 years & $1.47(0.95 ; 2.28)$ & 0.084 & $1.42(0.65 ; 3.10)$ & 0.381 \\
\hline$\leq 8$ years & $1.44(0.66 ; 3.15)$ & 0.359 & $1.45(0.93 ; 2.25)$ & 0.101 \\
\hline \multicolumn{5}{|l|}{ Marital Status ${ }^{2}$} \\
\hline Single & 1 & & 1 & \\
\hline Married & $1.11(0.61 ; 2.02)$ & 0.721 & $1.09(0.59 ; 1.98)$ & 0.787 \\
\hline Separated/Widowed & $1.15(0.75 ; 1.77)$ & 0.521 & $1.13(0.73 ; 1.75)$ & 0.595 \\
\hline \multicolumn{5}{|l|}{ Eating Habits ${ }^{3}$} \\
\hline Adequate & 1 & & 1 & \\
\hline Inadequate & $2.83(1.91 ; 4.21)$ & $<0.001$ & $2.77(1.85 ; 4.15)$ & $<0.001$ \\
\hline \multicolumn{5}{|c|}{ Excessive Alcohol Consumption ${ }^{3}$} \\
\hline No & 1 & & 1 & \\
\hline Yes & $1.33(0.42 ; 4.28)$ & 0.624 & $1.11(0.34 ; 3.64)$ & 0.867 \\
\hline \multicolumn{5}{|l|}{ Smoking $^{3}$} \\
\hline No & 1 & & 1 & \\
\hline Yes & $1.10(0.59 ; 2.05)$ & 0.755 & $1.14(0.60 ; 2.17)$ & 0.689 \\
\hline \multicolumn{5}{|l|}{ Displacement $^{3}$} \\
\hline Active & 1 & & 1 & \\
\hline Not active & $1.23(0.71 ; 2.14)$ & 0.457 & $1.12(0.62 ; 2.01)$ & 0.717 \\
\hline \multicolumn{5}{|l|}{ Activities at work ${ }^{3}$} \\
\hline Intense PA & 1 & & 1 & \\
\hline Moderate PA & $1.54(0.48 ; 5.00)$ & 0.469 & $1.77(0.52 ; 5.97)$ & 0.359 \\
\hline Sitting & $1.40(0.43 ; 4.57)$ & 0.577 & $1.55(0.46 ; 5.27)$ & 0.482 \\
\hline
\end{tabular}

OR: odds ratio; $\mathrm{Cl} 95 \%$ : confidence interval of $95 \% .{ }^{\dagger}$ crude analysis; ${ }^{\dagger+}$ adjusted analysis; Adjusted analysis by hierarchical level: ${ }^{1}$ Level distal; ${ }^{2}$ Level intermediate; ${ }^{3}$ Level Proximal; ${ }^{*} \mathrm{OR}$ and $\mathrm{Cl} 95 \%$ not estimated by the absence of individuals in the reference category.

Variables associated with SBC preparation were sex and inadequate eating habits in the crude and adjusted analyses. Women had 62\% fewer odds of being in the "preparation" stage compared to men and those with inadequate eating habits were more odds to be on that stage (175\%) (Table 4). 
Table 4. Odds ratios and confidence intervals for the crude and adjusted analyzes between the stages of behavior change "preparation" and sociodemographic indicators and health risk factors in technical-administrative servers of the UFSC. Florianópolis, SC, Brazil, 2012.

\begin{tabular}{|c|c|c|c|c|}
\hline \multirow{2}{*}{ Variable } & \multicolumn{4}{|c|}{ Preparation } \\
\hline & OR (IC95\%)† & $p$-value & OR (IC95\%)†† & $p$-value \\
\hline \multicolumn{5}{|l|}{$\operatorname{Sex}^{1}$} \\
\hline Men & 1 & & 1 & \\
\hline Women & $0.60(0.40 ; 0.89)$ & 0.012 & $0.62(0.41 ; 0.93)$ & 0.022 \\
\hline \multicolumn{5}{|l|}{ Age (years) ${ }^{1}$} \\
\hline $20-29$ & 1 & & 1 & \\
\hline $30-39$ & $1.00(0.45 ; 2.20)$ & 0.995 & $1.14(0.39 ; 3.35)$ & 0.811 \\
\hline $40-49$ & $1.89(0.89 ; 4.02)$ & 0.097 & $1.51(0.72 ; 3.15)$ & 0.270 \\
\hline $50-59$ & $1.63(0.79 ; 3.39)$ & 0.187 & $1.81(0.85 ; 3.87)$ & 0.124 \\
\hline $60-69$ & $1.29(0.44 ; 3.74)$ & 0.645 & $1.00(0.45 ; 2.20)$ & 0.995 \\
\hline \multicolumn{5}{|l|}{ Education ${ }^{2}$} \\
\hline$\geq 12$ years & 1 & & 1 & \\
\hline 9 to 11 years & $0.85(0.34 ; 2.15)$ & 0.734 & $0.82(0.32 ; 2.07)$ & 0.678 \\
\hline$\leq 8$ years & $1.00(0.62 ; 1.64)$ & 0.981 & $0.97(0.59 ; 1.59)$ & 0.895 \\
\hline \multicolumn{5}{|l|}{ Marital Status ${ }^{2}$} \\
\hline Single & 1 & & 1 & \\
\hline Married & $1.06(0.542 .07)$ & 0.865 & $1.07(0.54 ; 2.10)$ & 0.845 \\
\hline Separated/Widowed & $1.40(0.87 ; 2.25)$ & 0.166 & $1.41(0.87 ; 2.28)$ & 0.160 \\
\hline \multicolumn{5}{|l|}{ Eating Habits ${ }^{3}$} \\
\hline Adequate & 1 & & 1 & \\
\hline Inadequate & $1.86(1.22 ; 2.85)$ & 0.004 & $1.75(1.12 ; 2.70)$ & 0.013 \\
\hline \multicolumn{5}{|c|}{ Excessive Alcohol Consumption ${ }^{3}$} \\
\hline No & 1 & & 1 & \\
\hline Yes & $2.69(0.90 ; 8.03)$ & 0.076 & $2.17(0.71 ; 6.61)$ & 0.171 \\
\hline \multicolumn{5}{|l|}{ Smoking $^{3}$} \\
\hline No & 1 & & 1 & \\
\hline Yes & $1.54(0.83 ; 2.88)$ & 0.172 & $1.60(0.84 ; 3.09)$ & 0.154 \\
\hline \multicolumn{5}{|l|}{ Displacement $^{3}$} \\
\hline Active & 1 & & 1 & \\
\hline Not active & $1.58(0.83 ; 2.99)$ & 0.162 & $1.47(0.76 ; 2.85)$ & 0.256 \\
\hline \multicolumn{5}{|l|}{ Activities at work ${ }^{3}$} \\
\hline Intense PA & 1 & & 1 & \\
\hline Moderate PA & * & & * & \\
\hline Sitting & * & & * & \\
\hline
\end{tabular}

OR: odds ratio; Cl95\%: confidence interval of $95 \% .{ }^{\dagger}$ crude analysis; ${ }^{\dagger \dagger}$ adjusted analysis; Adjusted analysis by hierarchical level: ${ }^{1}$ Level distal; ${ }^{2}$ Level intermediate; ${ }^{3}$ Level Proximal; * $0 \mathrm{R}$ and $\mathrm{Cl}$ 95\% not estimated by the absence of individuals in the reference category.

\section{DISCUSSION}

The main findings of this study are that approximately $30.0 \%$ of technicaladministrative servers are in the "contemplation" stage, which represents the intention to change behavior related to PA, but not immediately. Servers with inadequate eating habits were more odds to be in the "precontemplation + contemplation" and "preparation" stages and women were fewer odds to be in the "preparation" stage. 
The prevalence of servers active on a regular basis ("action + maintenance") in the present study was similar to results found among university professors of Florianópolis, Brazil (38.9\%) ${ }^{10}$ and also among adults surveyed in southern Brazil (25.8\% of women and 33.6\% of men) $)^{17}$. This indicates the tendency of little PA on a regular basis, also seen in other countries ${ }^{18,19}$. This behavior becomes worrisome since it is a risk factor for chronic diseases such as heart disease, hypertension, obesity, type-2 diabetes, and musculoskeletal disease ${ }^{1-3}$. In the case of workers, this behavior may also predispose to occupational disorders such as RSI and WRMD ${ }^{4}$.

Women in this study were fewer odds to be in the "preparation" stage, which is controversial in literature $e^{9,17,20,21}$. A survey conducted in southern Brazil revealed that women were fewer odds to be in the "maintenance" phase for $\mathrm{PA}^{17}$. In Canada, another research found that women were more likely to be in the "preparation" stage for $\mathrm{PA}^{20}$. This tendency of women to present early stages for PA when compared to males was evidenced by systematic review ${ }^{9}$ and university students ${ }^{21}$. In general, women tend to become more involved in household tasks and domestic services, even those in the labor market, and men are more engaged in PA in leisure and planned / systematic activities ${ }^{22}$. The results of this study may not be similar to studies mentioned above because it included a population of workers, which features and labor functions are peculiar of the sample investigated here.

Technical-administrative servers with inadequate eating habits were more odds to be in the "pre-contemplation + contemplation" and "preparation" stages. The direct association between physical activity and diet has been shown in other studies ${ }^{23,24}$ as in the telephone inquiry conducted among adults from Florianópolis, SC Brazil, whose physical inactivity is associated with inadequate eating habits among women ${ }^{25}$. Among young adults in the state of Sergipe, Brazil, no relationship between eating habits and $\mathrm{SBC}$ for $\mathrm{PA}^{26}$ was observed. The adoption of healthy behavior can increase self-efficacy to other healthy behaviors, thus adopting a more active lifestyle can facilitate the adoption of healthy diet and vice versa ${ }^{23}$.

The results of this study showed no significant association between $\mathrm{SBC}$ for PA and variables age, schooling, marital status, excessive alcohol consumption, smoking, commuting and work activities. Silva and Pereira ${ }^{26}$ also found no correlation between SBC for PA, age, and marital status. A systematic review has found that individuals with a higher probability of being in the most advanced stages for PA (action and maintenance) are: young men, white, unmarried, higher schooling, nonsmokers and normal weight ${ }^{9}$. Other variables, such as excessive alcohol consumption, smoking, commuting and work activities need to be further investigated in literature.

It is noteworthy that a variable associated with certain behavior is not always the same as that associated with the change of this behavior ${ }^{17}$. In addition, little is known about variables that explain changes in human behavior and further studies should be carried out to elucidate them?

This research has some limitations. Losses and refusals observed may have led to some bias, requiring caution in interpreting the results. In 
addition, the question used to investigate the eating habits is generic and does not allow distinguishing food groups, food frequency, and portions consumed. The use of questionnaire and recall-type self-reported measures may allow some recall bias, or have their veracity questioned. However, it is emphasized that this study was conducted with a representative sample of technical-administrative servers and identified factors related to SBC for $\mathrm{PA}$, which does not yet have a consensus. Moreover, the most appropriate analysis model (multinomial regression) was used to analyze the $\mathrm{SBC}^{9}$. Few studies that investigated the $\mathrm{SBC}$ for $\mathrm{PA}$ in adults have been identified and the inconsistencies regarding the associations found in these studies indicates the need for further research to clarify these issues and be able to make more specific interventions for each population.

\section{CONCLUSION}

More than half of technical-administrative servers do not perform PA on a regular basis considering the SBC for PA (pre-contemplation, contemplation, and preparation). Women and servers with inadequate eating habits were more exposed to early SBC for PA.

The development of programs to promote PA aimed at these workers can use these results to outline more effective strategies, especially to groups more exposed to early stages ("pre-contemplation", "contemplation" and "preparation"). The theory of $\mathrm{SBC}$ for $\mathrm{PA}^{7}$ suggests that different approaches should be adopted for each stage, so actions aimed at workers that are in the "pre-contemplation" stage could involve interventions focusing on education for PA through meetings, lectures and guidance on health benefits in order to educate individuals about the importance of behavior change.

For workers in the "contemplation" stage, which includes individuals who have realized the importance of PA but did not begin the practice, actions should contemplate the creation of structured and easy-to-access locations for the practice of PA, with infrastructure and safety. These actions could be inserted into the work environment, so that they would have the opportunity to practice PA at breaks, for example.

For workers that are in the "preparation" stage, actions aimed at advance stage could include strategies to engage them in PA on a regular basis and the opportunity to experience different practices. Accordingly, the university could provide varied PA to employees and schedules to facilitate their participation. Additionally, nutrition professionals could be involved in these programs, since inadequate eating habits were associated with early SBC for PA.

\section{Acknowledgments}

We would like to thank the team at the Center for Research in Kinanthropometry and Human Performance and the Coordination of Improvement of Higher Education Personnel (CAPEs) for the awarded scholarships. 


\section{REFERENCES}

1. Roberts CK, Barnard RJ. Effects of exercise and diet on chronic disease. J Appl Physiol (1985) 2005;98(1):3-30.

2. Claas SA, Arnett DK. The Role of Healthy Lifestyle in the Primordial Prevention of Cardiovascular Disease. Curr Cardiol Rep 2016;18(6):56.

3. Sales-Peres SH, Guedes MF, Sa LM, Negrato CA, Lauris JR. Lifestyle of patients with diabetes mellitus type 1: a systematic review. Cien Saude Colet 2016;21(4):1197-1206.

4. Silva SGd, Silva MCd, Nahas MV, Viana SL. Fatores associados à inatividade física no lazer e principais barreiras na percepção de trabalhadores da indústria do Sul do Brasil. Cad Saúde Pública 2011;27(2):249-59.

5. Fransson EI, Heikkilä K, Nyberg ST, Zins M, Westerlund H, Westerholm P, et al. Job Strain as a Risk Factor for Leisure-Time Physical Inactivity: An IndividualParticipant Meta-Analysis of Up to 170,000 Men and Women: The IPD-Work Consortium. Am J Epidemiol 2012;176(12):1078-89.

6. Kirk MA, Rhodes RE. Occupation correlates of adults' participation in leisuretime physical activity: a systematic review. Am J Prev Med 2011;40(4):476-85.

7. Prochaska JO, Marcus BH. The transtheoretical model: applications to exercise. In: Dishman RK, editor. Advances in exercise adherence. Champaign: Human Kinetics; 1994.

8. Prochaska JO, Velicer WF. The transtheoretical model of health behavior change. Am J Health Promot 1997;12(1):38-48.

9. Dumith SC, Domingues MR, Gigante DP. Estágios de mudança de comportamento para a prática de atividade física: uma revisão da literatura. Rev Bras Cineantropom Desempenho Hum 2008;10(3):301-7.

10. Petroski EL, Oliveira MM. Atividade física de lazer e estágios de mudança de comportamento em professores universitários. Rev Port Cien Desp 2008;8(2):209-218.

11. Marcus BH, Banspach SW, Lefebvre RC, Rossi JS, Carleton RA, Abrams DB. Using the stages of change model to increase the adoption of physical activity among community participants. Am J Health Promot 1992;6(6):424-9.

12. Wilson DMC, Ciliska D. Lifestyle Assessment. Can Fam Physician 1984;30:1527-32.

13. Rodriguez Añez CR, Reis RS, Petroski EL. Versão brasileira do questionário "estilo de vida fantástico": tradução e validação para adultos jovens. Arq Bras Cardiol 2008;91(2):102-9.

14. Barros MVG. Atividades físicas no lazer e outros comportamentos relacionados à saúde dos trabalhadores da indústria no estado de Santa Catarina, Brasil: Universidade Federal de Santa Catarina; 1999.

15. Fonseca $\mathrm{S}$. Inatividade física no lazer e outros fatores de risco à saúde em industriários catarinenses, 1999-2004. 2005: Universidade Federal de Santa Catarina; 2005.

16. Victora CG, Huttly SR, Fuchs SC, Olinto MT. The role of conceptual frameworks in epidemiological analysis: a hierarchical approach. Int J Epidemiol 1997;26(1):224-7.

17. Dumith SC, Gigante DP, Domingues MR. Stages of change for physical activity in adults from Southern Brazil: a population-based survey. Int J Behav Nutr Phys Act 2007;4:25.

18. Hallal PC, Andersen LB, Bull FC, Guthold R, Haskell W, Ekelund U. Global physical activity levels: surveillance progress, pitfalls, and prospects. Lancet 2012;380(9838):247-57.

19. Tucker JM, Welk GJ, Beyler NK. Physical activity in U.S.: adults compliance with the Physical Activity Guidelines for Americans. Am J Prev Med 2011;40(4):454-61.

20. Bize R, Johnson JA, Plotnikoff RC. Physical activity level and health-related quality of life in the general adult population: a systematic review. Prev Med 2007;45(6):401-15. 
21. Quintino PL, Silva DAS, Petroski EL. Estágios de mudança de comportamento para atividade física em universitários e fatores sociodemográficos associados. Rev Bras Educ Fís Esporte 2014;28(2):305-14.

22. Potvin L, Gauvin L, Nguyen NM. Prevalence of stages of change for physical activity in rural, suburban and inner-city communities. J Community Health 1997;22(1):1-13.

23. Loprinzi PD. Association between accelerometer-determined physical activity and flavonoid-rich fruit and vegetable consumption among a national sample of U.S. adults. Prev Med Rep. 2016;3:58-61.

24. Loprinzi PD, Smit E, Mahoney S. Physical activity and dietary behavior in US adults and their combined influence on health. Mayo Clin Proc 2014;89(2):190-8.

25. Martins TG, Assis MAA, Nahas MV, Gauche H, Moura EC. Inatividade física no lazer de adultos e fatores associados. Rev Saúde Pública 2009;43(5):814-24.

26. Silva DAS, Pereira IMM. Estágios de mudança de comportamento para atividade física e fatores associados em acadêmicos de Educação Física. Rev Bras Ativ Fís \& Saúde 2012;15(1):15-20.

CORRESPONDING AUTHOR

Juliane Berria

Universidade Federal de Santa Catarina. Centro de Desportos.

Núcleo de Pesquisa em

Cineantropometria e Desempenho

Humano. Campus Universitário

Trindade - Caixa postal 476 - CEP

88040-900. Florianópolis, Santa

Catarina, Brasil.

Phone number/fax: +5548

37218562

E-mail: julianeberria@gmail.com 